\title{
REPRESENTAÇÕES FILOSÓFICAS SOBRE AS MULHERES DESDE A MODERNIDADE E O IMPACTO NA FIGURA DA PROFESSORA: PERSPECTIVAS ATUAIS
}

\author{
Leoni Maria Padilha Henning ${ }^{1}$
}

\begin{abstract}
RESUMO - O fio condutor do artigo atravessa o tema da mulher no processo das mudanças de diversas ordens interagindo com a visão filosófico-educacional gestada desde a modernidade. Exploraremos, nos limites deste escrito, as representações elaboradas pelos filósofos sobre as mulheres em cujas discussões sustentavam na "natureza" os traços característicos de gênero e que alcança, especialmente, a figura da professora. Na chamada pós-modernidade, a ideia de liquidez das noções, antes absolutas, apontam para a defesa da "construção de gênero", dentre outros temas. A vida passa a não ter o sentido antes passível de explicação pelas verdades e certeza dos conhecimentos, posto que na contemporaneidade predomina a crença na efemeridade, na valorização das experiências imediatas dos momentos únicos e fugazes, na busca incessante do prazer, o carpe diem. Apresentamos os traços distintivos de gênero na modernidade, tempo favorável a mudanças sobretudo para o universo feminino tal a transição ocorrida "do lar à projeção da mulher em outras instâncias sociais graças à emergência de condições objetivas" como a industrialização e outros fatores que vão possibilitando o "movimento feminista" que, no percurso histórico de organização revela diferentes momentos efervescentes de acúmulo de reivindicações e avanços, chamados de "ondas". Instituída também, no contexto do patriarcalismo, a "escola moderna", sustentada por valores burgueses, torna-se mais um fator de inspiração das mulheres para a sua libertação, engrossando a lista de reivindicações. Com um novo conjunto de ideias acopladas numa visão antimetafísica logo, contrária à "natureza humana", à verdade absoluta, ao saber definitivo e direcionador do comportamento na busca da ordem e progresso, chegamos ao modelo contemporâneo de sociedade frente a qual a escola vê-se impelida a se transformar, de alguma forma. Usamos autores emblemáticos para o tratamento do tema em fontes diversas como livros, artigos, trabalhos acadêmicos muito dos quais disponíveis na internet.
\end{abstract}

Palavras-chave: Modernidade. Educação Moderna. Transformações. Pós-modernidade. Professora.

ABSTRACT - The guiding thread of the article crosses the theme of women in the process of changes of different orders, interacting with the philosophical-educational vision created since modern times. We will explore, within the limits of this writing, the representations elaborated by philosophers about the women in whose discussions they supported in "nature" the characteristic features of gender and that reach, in particular, the figure of the teacher. In the so-called post-modernity, the idea of liquidity of notions, which used to be absolute, now points to the defense of the "construction of gender", among other themes. Life becomes meaningless whose meanings were explained before by the truths and certainty of knowledge, since in contemporaneity the belief in ephemerality prevails, in the valuing of immediate experiences of unique and fleeting moments, in the incessant search for pleasure, the carpe diem. We present the distinctive features of gender in modernity, a time favorable to changes, especially for the female universe, such as the transition that occurred "from the home to the projection of women in other social instances thanks to the emergence of objective conditions" such as industrialization and other factors that enable the "feminist movement" which, in the historical course of organization, reveals different effervescent moments of accumulation of claims and advances, called "waves". Also instituted in the context of patriarchy, the "modern school", supported by bourgeois values, becomes yet another factor of inspiration for women for their liberation, thickening the list of demands. With a new set of ideas coupled with an anti-metaphysical vision, contrary to "human nature", to absolute truth, to the definitive knowledge and direction of behavior in the search for order and progress, we arrive at the contemporary model of society in front of which the school sees herself impelled to transform, in some way. We use emblematic authors to deal with the theme in various sources such as books, articles, academic works, many of which are available on the internet.

Keywords: Modernity. Modern Education. Transformations. Postmodernity. Teacher.

\footnotetext{
${ }^{1}$ Professora Sênior do Programa de Pós-graduação em Educação da Universidade Estadual de Londrina-Paraná, graduada em Filosofia (UFPR, 1974); master of Education (MSU, 1977); master of Science (ISU, 1991); doutora em Educação (UNESP, 2003); pós-doutora em Filosofia (UFSC, 2014). É líder dos Grupos de Pesquisa: "Teorias filosófico-educacionais e seus impactos na Filosofia da Educação brasileira"; "Pesquisa em Filosofia da Educação: tradições e tendências"; e, é integrante do Grupo de Pesquisa "Filosofia, educação e condição humana". E-mail: leoni.henning@yahoo.com
} 
Introdução - A modernidade conjuga fatores do nosso interesse para desenvolvermos a presente reflexão, a saber, 1) sustenta características bem definidas com respeito à antropologia feminina; 2) abriga acontecimentos pertinentes à compreensão do tema, como é o caso da industrialização, dentre outros; 3) possibilita a emersão do movimento feminista como conjunto de reivindicações em defesa da mulher diante das várias situações de interdições à sua autonomia, demonstrando o necessário esforço para a conquista de uma pauta de atividades facilitadora à sua inserção na nova ordem social; 4) constitui-se no lugar que ensejou o surgimento da escola moderna em que às mulheres foi sugerida a representação de mestras da "humanidade ou da Pátria". Para apresentação da problemática ampliamos as questões que enredam o tema, antes mesmo de tratar diretamente da "mulher interpretada pelos filósofos" ideias que oferecem sustentação aos axiomas imperantes na modernidade sobre o feminino - a despeito de algumas dessas representações já estarem presentes ainda em tempos anteriores na história do pensamento. É a partir do cenário da modernidade que inicialmente pontuamos alguns traços importantes constituídos na época e que se alongam nos séculos posteriores chegando na pós-modernidade, com a preocupação de perceber o impacto de tais concepções na sociedade em geral, e na Educação em particular, especialmente, no que diz respeito à figura da professora. Sabemos do impacto da industrialização nas sociedades a partir do século XVIII, desenvolvendo-se admiravelmente no século XIX e seguintes. Após a Revolução Industrial lançar-se na Inglaterra e agitar o perfil brando das ditas sociedades tradicionais para uma nova e mais dinâmica organização social, as mulheres começaram a gradativamente ser melhor aceitas no desempenho de algumas atividades econômicas regulamentadas. Entretanto, suspeita-se que a expectativa dessa mudança apontava para maiores lucros aos industriais, uma vez que as mulheres, por se posicionarem socialmente numa condição marginalizada, poderiam obter pagamentos menores - questão que será retomada adiante.

\section{Do lar à projeção da mulher em outras instâncias sociais: emergência de condições} objetivas favoráveis - O século XIX foi um tempo de utopias calcadas no cientificismo e no delineamento das esferas burguesas de poder. Neste cenário, tanto o positivismo quanto o marxismo desempenharam importante papel nas discussões do período. O primeiro, de perfil conservador, pretendia manter a ordem e reforçá-la por meio de reformas; enquanto o segundo buscava subverter a ordem de forma revolucionária. No Brasil, o positivismo levou vantagens por se associar à República, apreciada como esperança de tempos mais desenvolvidos. $\mathrm{O}$ marxismo deslanchou somente no século XX, principalmente com o surgimento e fortalecimento do proletariado em decorrência da industrialização no país. É neste contexto

\begin{tabular}{|l|l|l|l|l|}
\hline Qonista Dialectus & Ano 10 & n. 22 & Edição Especial, junho 2021 & p. 134 - 158 \\
\hline
\end{tabular}


que se revela um interesse pelo potencial guardado na figura feminina, interpretado por diferentes focos, logo, também, com expectativas de acordo com os diferentes princípios e finalidades. Assim, no positivismo essa personagem se destaca como a "educadora da Humanidade" devendo, portanto, ser educada de acordo com a doutrina comtiana e se ocupar, na sequência, com as funções apropriadas ao âmbito doméstico. Todavia, os ditames do marxismo tratam de interpretar a mulher como um agente revolucionário importante, como ilustrado nas Cartas de longe, 1917 ( ${ }^{\text {a }}$ Carta) por Lenin² (1979, p. 59): "Não se pode assegurar a verdadeira liberdade, não se pode edificar a democracia - sem falar de socialismo - se não chamamos as mulheres ao serviço cívico, na milícia, na vida política, se não a tirarmos da atmosfera brutal do lar e da cozinha". Referindo-se à problemática da igualdade jurídica de direitos entre o homem e a mulher que, a partir do casamento se estendeu para as instâncias privada e pública, Engels ${ }^{3}$ assim explica e oferece sugestão.

\begin{abstract}
As coisas mudaram com o advento da família patriarcal e mais ainda com a família individual monogâmica. O governo do lar perdeu o seu caráter social. A sociedade já nada mais tinha a ver com ele. O governo do lar transformou-se em serviço privado; a mulher converteu-se na primeira criada, sem participação na produção social. Só a grande indústria dos nossos dias lhe abriu de novo - embora apenas para a proletária - o caminho da produção social. Mas fê-lo de maneira tal que, se a mulher cumpre os seus deveres domésticos no seio da família, fica excluída do trabalho social e nada pode ganhar; e, se quer tomar parte da indústria social e ganhar a sua vida de maneira independente, lhe é impossível cumprir com as obrigações domésticas. Da mesma forma que na fábrica, é isso o que acontece à mulher em todos os setores profissionais, inclusive na medicina e na advocacia. A família individual moderna baseia-se na escravidão doméstica, franca ou dissimulada, da mulher, e a sociedade moderna é uma massa cujas moléculas são as famílias individuais.

Hoje, na maioria dos casos, é o homem que tem que ganhar os meios de subsistência da família, pelo menos nas classes possuidoras; e isso lhes dá uma posição dominadora, que não exige privilégios legais especiais. Na família, o homem é o burguês e a mulher representa o proletário. No mundo industrial, entretanto, o caráter específico da opressão econômica que pesa sobre o proletariado não se manifesta em todo o seu rigor senão quando suprimidos todos os privilégios legais da classe dos capitalistas e juridicamente estabelecida a plena igualdade das duas classes. A república democrática não suprime o antagonismo entre as duas classes; pelo contrário, ela não faz senão propiciar o terreno do qual o combate vai ser decidido. De igual maneira, o caráter particular do predomínio do homem sobre a mulher na família moderna, assim como a necessidade e o modo de estabelecer uma igualdade social efetiva entre ambos, não se manifestarão com toda a nitidez senão quando o homem e mulher tiverem, por lei direitos absolutamente iguais. Então é que se verá que a libertação da mulher exige, como primeira condição, a reincorporação de todo o sexo feminino na indústria social, o que, por sua vez, requer a supressão da família individual enquanto unidade econômica da sociedade. (ENGELS, 1984, p. 113-114, itálicos do autor, grifos nossos).
\end{abstract}

2. Vladimir Ilyich Ulianov (Simbirsk, 1870; Gorki, 1924), mais conhecido pelo pseudônimo Lenin ou Lenine. Foi um revolucionário comunista, político, teórico russo e chefe de governo em dois períodos: na Rússia Soviética de 1917 a 1924 e na União Soviética de 1922 até a morte.

${ }^{3}$ Friedrich Engels (Wuppertal, Alemanha, 1820; Londres, Reino Unido, 1895), autor da obra Origem da família, da propriedade privada e do Estado. Foi empresário industrial e teórico revolucionário prussiano. Com Karl Marx fundou o chamado socialismo científico ou marxismo e coautorou diversas obras, sendo a mais conhecida, o Manifesto Comunista.

n. 22

Edição Especial, junho 2021

p. $134-158$ 
Sabemos que o Iluminismo ao levantar a bandeira da liberdade, igualdade e fraternidade, impulsionou as questões dos séculos que se seguiram referentes às desigualdades, incluindo aquelas que atingiam as mulheres ${ }^{4}$. Tais ideais discutidos no bojo da prioridade à razão sobre o sentimento traziam outras dificuldades. Hume e Condorcet, por exemplo, argumentam que a discussão sobre a igualdade de direitos deve reconhecer que as diferenças entre os sexos são adquiridas socialmente, portanto, são culturais e não naturais. Por outro lado, Kant e Rousseau, defensores dos mesmos ideais fundamentam a desigualdade de direitos pautados na noção de "natureza" advogando que as diferenças observadas entre os sexos se devem à natureza racional inferior da mulher em relação ao homem - temas que serão tratados posteriormente.

O advento da industrialização marca um divisor de águas na organização social, deixando para trás os demarcados traços da sociedade tradicional enquanto a sociedade que se anuncia, e em cuja configuração da divisão do trabalho incorporou um novo lugar da mulher, possibilita a ela (melhor dizendo, a um segmento do universo feminino) a inclusão na fábrica para a realização de suas atividades. Contudo, a este segmento feminino se atribui o perfil equivalente ao proletariado do sistema capitalista. No entanto, admitamos, tal alternativa surgida no cenário moderno - a despeito de críticas discutidas à frente - permite-lhe sua presença no mercado de trabalho mostrando-lhe outras oportunidades que mobilizarão ações para novas conquistas. Paralelamente, vemos muitas alterações acontecerem no processo industrial, exigindo novas capacitações e adaptações frente, por exemplo, ao automatismo, mecanização, regulação do tempo de trabalho, dentre outras, o que leva à necessidade reivindicatória de educação e de leis trabalhistas correspondentes aos novos papéis e, em cujo bojo dos debates, questões sobre o trabalho feminino e infantil ganham certo destaque ${ }^{5}$. Junto à industrialização não devemos deixar de considerar a urbanização em cujas cidades se alastram as periferias, fenômeno parte decorrente do gradativo acúmulo populacional em torno das indústrias onde vivem um cada vez maior segmento social, o proletariado, formado por ampla maioria de imigrantes e migrantes em busca de melhores oportunidades e condições de vida. Neste cenário aparece, para algumas mulheres, a oportunidade de ingressarem no mercado de trabalho, especialmente, nas fábricas, pela forte razão de ser a mão-de-obra feminina mais

\footnotetext{
${ }^{4}$ Convidamos o leitor a observar nas Ações feministas", tratadas mais adiante, a data e observação especialmente sobre o ano 1919.

${ }^{5} \mathrm{Na}$ contemporaneidade, esse processo se complexifica com a globalização e o incremento espetacular das tecnologias que, certamente, atingem os papéis sociais e ameaçam a exclusão, surgindo a necessidade de constante capacitação e adaptação.
}

\begin{tabular}{|l|l|l|l|l|}
\hline Revista 2 ialectus & Ano 10 & n. 22 & Edição Especial, junho 2021 & p. 134 - 158 \\
\hline
\end{tabular}


barata, favorecida pela baixa autoestima fazendo com que essas mulheres aceitassem uma remuneração inferior, ainda quando no desempenho da mesma função realizada por homens. Fora do lar e contribuindo com o sustento da família, os encargos domésticos, contudo, continuaram sob a exclusiva responsabilidade da mulher. Há uma marcante hierarquização em relação aos relacionamentos afetivos, colocando homens e mulheres em esferas polarizadas, destinando os primeiros para atividades atinentes à sua posição de chefes da família, provedores e garantidores da sobrevivência familiar, logo, descompromissados com o funcionamento doméstico e cuidados com os filhos. A mulher, na outra ponta, se destina ao que diz respeito à reprodução, própria da sua natureza, mas também a responsabilidade pelo andamento dos serviços da casa, criação dos filhos e cuidado dos idosos e doentes. Aos homens cabem as atividades no espaço público, ficando as mulheres principalmente ocupadas com o labor doméstico, e as atividades relativas à "educação de verniz" destinadas àquelas das classes mais altas. No Brasil, o movimento das profundas mudanças na virada dos séculos XIX e XX alteraram sobremaneira as condições de trabalho e o perfil da sociedade.

[...] o início do século XX, foi marcado no Brasil por um crescimento da industrialização e, consequentemente, o surgimento do movimento operário. [...] esse movimento mantinha as mulheres numa condição de submissão, uma vez que elas se incluíam no movimento como trabalhadoras, mas não como líderes. O movimento operário via, ainda, as mulheres como frágeis para esse contexto e necessitadas da proteção dos companheiros homens. Talvez aqui se iniciasse uma das primeiras "perdas" significativas de espaço de trabalho dos homens para as mulheres, o que era em parte uma novidade e, em parte, uma ameaça ao papel social masculino, enquanto provedor da família. (COELHO; BAPTISTA, 2009, p. 90, grifos nossos).

Esse retrato espelha a realidade de muitas mulheres que se viam travadas por interdições à sua penetração em algumas esferas sociais de atuação para a execução de tarefas que almejavam. Isso ocorreu em diferentes níveis de dificuldades de acordo com os diversos países e culturas. No Brasil, a nossa Constituição Federal estabelece o respeito quanto à igualdade entre o homem e a mulher, considerando a revolução feminina como grande elemento transformador da configuração social - apesar dos muitos problemas sobre o tema. O movimento feminista, entre outros, é, pois, considerado parte representativa do que se configura como época pós-moderna e nos oferece elementos importantes para compreender o período.

Ações feministas - Há mais ou menos dois séculos, o feminismo vem se constituindo num movimento que se ocupou bravamente contra a dominação masculina no universo social, cultural, político, e nas instâncias gerais de algumas nações. Grosso modo, as mulheres começaram a se insurgir tentando - com muitas lutas acompanhadas por frustrações, mas

\begin{tabular}{|l|l|l|l|l|}
\hline Qonista Dialectus & Ano 10 & n. 22 & Edição Especial, junho 2021 & p. 134 - 158 \\
\hline
\end{tabular}


também, por conquistas - a promoção da emancipação feminina e a defesa da igualdade de gênero, ainda em curso. Do movimento feminista resultaram posições inovadoras quanto ao papel das mulheres na família, à defesa da sua participação política, ao questionamento quanto à sexualidade e ao trabalho doméstico e à divisão das tarefas entre os sexos, à responsabilidade no cuidado com as crianças, dentre outras. Quanto a esse processo de lutas e reivindicações, nos encontramos nos dias atuais, na "terceira onda do movimento feminista" caracterizada pela pluralidade em sua composição em que se observa uma interseccionalidade de grupos, considerando os recortes de raça, classe, gênero, etc., o que evidentemente atinge os vários setores da sociedade e suas instituições como a família e a escola, dentre outras. Esse assunto será detalhado mais adiante. Assim, vemos emergir um conjunto de reivindicações femininas que podem ser agregadas à ideia de "direitos humanos", incluindo também outros grupos como os LGBTs, as mulheres negras, as praticantes das religiões não-tradicionais, etc., e temas como aborto, direito de igualdade profissional, etc. O movimento feminista, primeiramente, denuncia as práticas desfavoráveis atribuídas ao regime tradicional do patriarcado, machismo, autoritarismo, como ainda, aponta a falta de suportes legais para a valorização das mulheres dentro dos vários setores da sociedade em condições favorecedoras ao seu crescimento como ser social, cultural, produtivo, político e participativo, destacando nesse contexto, a questão do direito ao voto e à inserção no mundo do trabalho. A "primeira onda do movimento feminista", sufragista, foi assim chamada pela bandeira do direito ao voto, pela participação política e alegação de maiores oportunidades profissionais. Esse momento, designado como vertente liberal do movimento, é interpretado positivamente pelas forças e conquistas, mas é criticado pelo fato de as mulheres terem sido cooptadas pelo liberalismo e, como tal, sendo objetificadas pelo consumo e terem se tornado parceira do capital. As teorias socialista e marxista aparecem na época, e figuras como Rosa Luxemburgo (1871-1919) simbolizam o período. No Brasil, a questão do voto foi pauta desde a Constituinte de 1891, mas só devidamente incorporada em 1932 quando a mulher se tornou cidadã adquirindo tal direito - embora, tendo sido somente em 1934 que o voto feminino passa a ser regulamentado no país para mulheres de "todas as rendas, origens ou estado civil", uma vez que dois anos antes, somente solteiras e viúvas com renda própria e mulheres casadas "com permissão do marido" é que podiam votar. Com o fortalecimento do movimento feminista do início do século XX, é que atuantes do movimento sufragista, influenciadas, sobretudo, pela luta por direitos políticos das mulheres nos EUA e na Europa, foi possível realizar tal intento. Hoje, o contingente feminino representa mais da metade

${ }^{6}$ Sobre as ondas do feminismo, ver FRANCHINI, 2017.

\begin{tabular}{|l|l|l|l|l|}
\hline Q & Anoista 10 & n. 22 & Edição Especial, junho 2021 & p. 134 - 158 \\
\hline
\end{tabular}


do eleitorado ${ }^{7}$. Quanto ao exercício da vida política, a maioria ainda entra nessa esfera levada pelo pai, marido ou companheiro. O apelo social à mulher como a primeira responsável ao atendimento das reivindicações familiares, em primeira instância, tem inibido a busca por tarefas mais desafiadoras. É preciso que a política considere a perspectiva feminina, pautando temas de seu interesse.

Foi a partir da década de 60 que o cenário da vida pública feminina mudou sobremaneira e sua participação se intensificou. Neste período, vemos surgir no movimento a vertente do "feminismo radical", já na "segunda onda do movimento" - este, iniciado desde os anos 50 indo até os anos 90. A vertente mencionada adota uma perspectiva biológico-social, tematizando a opressão em base do sexo, defendendo as condições próprias do corpo feminino como aquele que, por exemplo, abriga um útero e cujas demandas devem beneficiar as condições necessárias para a sua liberação comportamental, como uso de anticoncepcionais, dentre outras. A ciência é vista como campo dominado pelos homens, logo propõe uma epistemologia feminina. A segunda onda se ocupa em analisar as estruturas e instituições opressivas e o poder delas derivado. As reivindicações pela abertura democrática, por demandas sociais como política salarial, melhorias nos serviços públicos, continuam muito em alta, etc. Em 1968, as mulheres participaram do Movimento Nacional contra a Carestia; em 1910 do Movimento de Luta por Creches; em 1974, do Movimento Brasileiro pela Anistia; em 1975, criaram os Grupos Feministas e Centros de Mulheres, dentre outros. No geral, podemos dizer, que o movimento feminista significa a efetivação do descontentamento acumulado pelos prejuízos impostos às mulheres de participarem amplamente da vida social, tendo por base as “crenças sobre a sua natureza e as possíveis atribuições decorrentes desses traços" - assunto que merecerá o devido tratamento neste trabalho. Foi à duras penas, e gradativamente, que as mulheres conquistaram o que se segue, iniciando esses avanços já antes mesmo de 1932 com o já mencionado direito ao voto. 1) Lei Geral em 1827, de 15 de outubro: estabelece que as meninas brasileiras podem frequentar colégios e estudar além da escola primária. Na verdade, com a ascensão da burguesia, houve no ocidente do século XIX a preocupação de se dotar as mulheres de Educação. No Brasil, a influência do que ocorrera nos Estados Unidos e Europa levou ao movimento favorável às mulheres para a Educação e trabalho terciário (ensino,

\footnotetext{
7. De acordo com o site https://agenciabrasil.ebc.com.br, nas eleições de 2020, dos 147, 9 milhões de eleitores aptos a votar, [...] as mulheres somam 77.649 .569 eleitores $(52,49 \%)$ do total. Os homens totalizam 70.228 .457 eleitores (47,48\%). Outras 40.457 pessoas não declararam o gênero, representando $0,03 \%$ do eleitorado". Assim, "Mulher, com ensino médio e de 35 a 59 anos é o perfil majoritário do eleitor que votará nas eleições de 2020 , segundo o Tribunal Superior Eleitoral (TSE)".
}

\begin{tabular}{|c|c|c|c|c|}
\hline Qovita Dialeatus & Ano 10 & n. 22 & Edição Especial, junho 2021 & p. $134-158$ \\
\hline
\end{tabular}


escritórios, etc.). Entre 1880 a 1920, grande parte dos países europeus criou o ensino secundário para mulheres, o que aconteceu em 1891 na Alemanha concedendo o Abitur ${ }^{8}$ às mulheres. Na França, Julie Daubié ${ }^{9}$ conquistou, com esforço, o direito ao exame de bacharelado, com intervenção da imperadora. Com a unificação dos bacharelados em 1924, os programas se tornaram mistos ${ }^{10}$. A chamada "Educação de verniz" designava as atividades de refinamento estético praticada pelas mulheres da alta burguesia, própria dos Salões, enquanto que para as mulheres da pequena burguesia ou as proletárias se oferecia uma Educação mais técnica, ocupacional, preparatória às atividades mais rudimentares da vida familiar, mas também moral, para evitar os riscos da degradação. Hoje, a situação é diferente no Brasil onde as mulheres têm tido maiores oportunidades de acesso às universidades, segundo relatório Education of Glance, 2019, divulgado pela Organização para a Cooperação e Desenvolvimento Econômico. Nesse sentido, essa luta vem sendo exitosa, já que o acesso desde a Educação básica, por muito tempo, foi negado ou pouco incentivada às meninas. 2) Em 1832 é publicado o livro Direitos das mulheres e injustiças dos homens de Nísia Floresta ${ }^{11}$, considerado obra fundadora do feminismo brasileiro. A autora reforça que a mulher é tão capaz quanto o homem de assumir cargos de liderança e qualquer outra função, denunciando o mito da superioridade masculina. 3) Em 1852 surge o Jornal das Senhoras, editado e direcionado por mulheres, advogando que os interesses femininos para o tempo livre fossem além de aprender piano, bordado ou costura. Depois disso, outros jornais apareceram, como o Bello Sexo (1862) e O Sexo Feminino (1873). 4) 19 de abril de 1879, data que determina o direito das mulheres ao acesso às faculdades para cursarem o ensino superior, assim como já acontecia com os homens. Apesar de estar dentro da legalidade, a maioria enfrentava o preconceito ao frequentar os espaços universitários. 5) Em 1887 temos a primeira médica brasileira e segunda na América Latina, Rita Lobato Freitas, formada pela Faculdade de Medicina da Bahia. Mesmo protegida pela lei que permitia o ingresso de mulheres na faculdade, Rita sofreu preconceito daqueles que ainda achavam que estudar era "coisa de menino". Para a conclusão do curso, a médica elabora uma tese com

\footnotetext{
${ }^{8}$ Abitur - exame conclusivo do ensino secundário para o ingresso em universidades alemãs e de outros países equivalente ao High School diploma americano e ENEM no Brasil.

${ }^{9}$ Jornalista francesa e primeira mulher a se formar numa universidade em seu país - Lyon, 1861.

${ }^{10}$ Para mais detalhes, consultar MELLO, 2007, p. 34.

${ }^{11}$ Nísia Floresta Brasileira Augusta, pseudônimo de Dionísia Gonçalves Pinto, (Papari, 12 de outubro de 1810 Rouen, França, 24 de abril de 1885) uma educadora, escritora e poetisa brasileira. Considerada a precursora da Educação feminista no Brasil, com protagonismo nas letras, jornalismo e movimentos sociais. Mulher culta, publicou parte de suas obras em francês e italiano, muitas delas ainda permanecendo sem tradução ao português; relacionava-se com importante intelectualidade, destacando Alexandre Dumas, Victor Hugo e Auguste Comte com o qual manteve estreita amizade até a sua morte, especialmente, por admirá-lo como intelectual devotado a erigir um lugar de maior proeminência à mulher em sua concepção de República.
}

\begin{tabular}{|c|c|c|c|c|}
\hline Q Rovista Dialectus & Ano 10 & n. 22 & Edição Especial, junho 2021 & p. $134-158$ \\
\hline
\end{tabular}


temática feminina: operação cesariana. 6) Em 1918: Maria Lacerda de Moura publica Em Torno da Educação entrando na lista das obras importantes como marco do feminismo brasileiro. Neste livro a autora defende o processo educacional para a libertação feminina, afirmando que a instrução é um fator indispensável na transformação da vida das mulheres. 7) Em 1919 ocorre a aprovação da Resolução que determina salários iguais para homens e mulheres que exercem a mesma função. Apesar de a Conferência do Conselho Feminino da Organização Internacional do Trabalho (OIT) ter conquistado este dispositivo legal, sabemos que, infelizmente, a igualdade ainda não foi plenamente alcançada. 8) Em 1921 é realizado o primeiro jogo de futebol entre mulheres dos bairros de Tremembé e Cantareira (SP), evento noticiado por jornais impressos da época (dirigidos certamente por homens) como algo "curioso e cômico". 9) Em 1928 é eleita no Brasil a primeira prefeita, Alzira Soriano de Souza, quando ainda nem havia o voto feminino pleno. Posteriormente, tivemos uma sequência de cargos políticos assumidos por mulheres, como: Maria Luiza Fontenele, prefeita de uma capital brasileira, Fortaleza; Iolanda Fleming, governadora, no Acre; Luiza Erundina, prefeita de São Paulo; Dilma Rousseff, presidente do Brasil, etc. 10) Em 1932, a nadadora Maria Lenk se torna a primeira mulher a participar das Olimpíadas, apesar de a primeira participação do Brasil nos Jogos Olímpicos já ter ocorrido em 1920. Interessante notarmos as alterações ocorridas no período referentes às concepções sobre a ginástica e esporte adequados às mulheres. Em relação ao discurso médicohigienista do início do século $\mathrm{XX}$, vemos a importância atribuída à prática da ginástica feminina, estabelecendo que o corpo feminino deveria ser fortalecido sim pela ginástica, mas aquela adequada ao sexo e às peculiaridades das mulheres, pois são estas que geram "[...] os filhos da pátria, o bom soldado e o elegante e civilizado cidadão" (FERNANDES, 2010, p. 02). Nesse sentido, a ginástica mais adequada seria aquela que fortalecesse e, ao mesmo tempo, acentuasse as formas femininas, com graça e leveza, como os exercícios suaves junto com música, canto e dança. Podemos, então, notar que por trás de todo o discurso de higiene e eugenia, se conservava a preocupação com a feminilidade (beleza) da mulher, sendo por isso proibida diversas práticas ditas prejudiciais a sua delicada natureza, como é o caso das lutas, saltos, transposição de obstáculos, entre outros que compunham os métodos ginásticos, por desenvolverem a força muscular, podendo então, comprometer a mais singela aparência feminina. Essa visão sobre a mulher se sustentava também em argumentos moralistas e proposições de virtudes compatíveis ao ideal feminino cujas condições ao seu atendimento necessitava de proteção, pois se tratava de seres belos, mas frágeis. Conquanto se incentivava as atividades consideradas mais adequadas à natureza feminina como, a prática do piano, ballet

\begin{tabular}{|c|c|c|c|c|}
\hline Qovista Dialectus & Ano 10 & n. 22 & Edição Especial, junho 2021 & p. $134-158$ \\
\hline
\end{tabular}




\section{REPRESENTACÕES FILOSÓFICAS SOBRE AS MULHERES DESDE...}

Leoni Maria Padilha Henning

clássico, canto e os exercícios físicos próprios à sua fragilidade e beleza, não se aconselhava os esportes violentos que exigiam força, como também, alguns tipos de arte tal como o teatro, que eram mal vistos em razão dos riscos aos bons costumes e, por conseguinte, à formação feminina. Tal panorama foi alterado no período de 30 a 80, quando aparece, por exemplo, a publicidade que pouco a pouco subtraiu o discurso médico-higienista, ditando outros ideais de aparência. A propaganda vinculada à indústria da beleza com seus vários artefatos como maquiagens, loções cosméticas, etc., mostrando que tais itens podem agregar à prática de exercícios físicos alguns fatores compatíveis ao universo feminino. Assim, temos novos padrões de aparência física associados aos novos tempos e reforçados pela mídia, tornando a mulher desafiada a atingir tais padrões. Temos ainda as revistas femininas que se constituem num veículo importante de propagação do novo padrão, especialmente, desde o final dos anos 30. $\mathrm{O}$ discurso de restrição à prática feminina ainda afastava das mulheres determinadas atividades entendidas como "inapropriadas à sua natureza", tidas como "masculinizantes" - tal como o boxe e os saltos com vara, triplo, etc. Nesse particular, podemos lembrar as preocupações de Rousseau:

Cultivar nas mulheres as qualidades do homem e deixar de lado as que lhes são próprias é, pois, claramente trabalhar contra elas. As mais astutas percebem isso bem demais para se enganarem; ao procurarem usurpar as nossas vantagens, não abandonam as suas; acontece, porém, que, não podendo harmonizar umas e outras porque são incompatíveis, elas permanecem abaixo de seu nível sem alcançar o nosso, e perdem a metade de seu valor. Mãe judiciosa, acreditai em mim e não façais de vossa filha um cavalheiro, como que para desmentir a natureza; tornai-a uma dama, e podeis estar certa de que será melhor para ela e para nós (ROUSSEAU, 1995, p. 501).

Ainda no século XX se insistia na "idealização da mulher" conforme os ditames de uma "suposta natureza", mesmo que com outros enquadramentos. Pregava-se como ideal, neste período, um corpo feminino magro/esguio correspondente ao daqueles das estrelas de cinema. A partir daí há o avanço das academias de dança e ginástica mais apropriadas ao público feminino. Estes espaços foram pensados de forma a oferecerem às mulheres uma prática segura e privada de exercícios físicos de acordo com suas "necessidades" relacionadas ao cuidado do corpo e aparência, colocadas pela publicidade e mídia. É preciso observar que a Segunda Guerra Mundial se constituiu em um marco importante no que se refere à "emancipação" feminina e sua relação com a ginástica e o próprio corpo. A ausência dos homens em importantes setores da sociedade no período bélico, fez com que as mulheres se inserissem nos espaços e profissões antes ocupados somente pelo sexo oposto. Assim, já na década de 70 em plena "segunda onda do feminismo", vemos as mulheres se interessarem por esses espaços masculinos, aprendendo

\begin{tabular}{|l|l|l|l|l|}
\hline Qovista Dialectus & Ano 10 & n. 22 & Edição Especial, junho 2021 & p. 134 - 158 \\
\hline
\end{tabular}




\section{REPRESENTACÕES FILOSÓFICAS SOBRE AS MULHERES DESDE...}

Leoni Maria Padilha Henning

com maior segurança a interagir e realizar atividades orientadas também pelos homens ${ }^{12}$. Tendo rompido as barreiras até então proibidas, a mulher passa a frequentar ambientes e praticar ginástica, originariamente propostos ao sexo oposto, como a musculação. Porém, a ginástica masculina, como os treinos de força, começa a atrair as mulheres para se aproximarem mais das imagens difundidas pelas propagandas publicitárias. Com os anos 80, o corpo feminino aproveita as academias para tonificar a musculatura e "malhar". "Malhar como se malha o ferro, [...] significando o intenso esforço embutido nesse significante. Trabalhar diferentes partes do corpo que precisam ser modificadas. [...] o corpo é visto como fragmento; cada parte podendo ser reesculpida, consertada, desconectada de um todo" (DEL PRIORI apud FERNANDES, 2010, p. 03, grifos nossos). A ideia de fragmentação na pós-modernidade se estende à vida cotidiana. É como se a suposta unidade moderna, seu equilíbrio, se desfazem.

No caso das academias, elas intensificam a procura pelo público feminino que buscam na musculação a possibilidade de exercitar parte por parte do seu corpo com o uso de aparelhos e exercícios específicos, na intenção de esculpi-lo conforme o mais atual modelo de corpo perfeito. No final do século XX, à beleza se associa a saúde e a busca por qualidade de vida e bem estar com a cultura do fitness, impulsionada pela mídia. Consumidoras do mercado, as mulheres se rendem aos apelos da "indústria da beleza" que veiculam um arsenal de itens próprios para a realização do corpo perfeito e saudável, pele perfeita e sedosa, leveza nos gestos, e sucesso certo atraídas pelos meios de comunicação, internet e celulares. O alcance dessa admirável aparência se fundamenta mais no esforço e disciplina do que numa dádiva da "natureza" e, como tal, configura-se no único meio de realização com saúde, sucesso e felicidade. Os anos 90 traz também a questão da identidade e ancestralidade pelas mulheres negras, assim como surgem outros grupos com suas particularidades, o que faz surgir a "terceira onda do movimento ${ }^{13}$ " pulverizado por filosofias identitárias cravadas na interseccionalidade, num contexto de enormes alterações do ponto de vista econômico, político e cultural. O panorama é complexo e plural. Ademais, a nova engenharia do corpo agrega o aparato das novas tecnologias que além de oferecerem maior visibilidade na comunicação, trazem a promessa cada vez mais sofisticadas para a mulher "corrigir" o que a tecnologia anterior não

\footnotetext{
${ }^{12}$ A esse respeito, o texto de FERNANDES, 2010, é bem explicativo.

13 "É no seio da terceira onda que Judith Butler desenvolve, em sua tese de doutorado Problemas de gênero (1990), sua teoria de gênero enquanto performance/performatividade (que rompe o paradigma da divisão entre natural e social, sexo e gênero), lançando as sementes para a teoria queer que se desenvolveria mais profundamente ao longo da década de 90" (FRANCHINI, 2017). Anuncia-se na atualidade a "quarta onda do feminismo" com a pauta em defesa de medidas contra a opressão, a violência, a cultura do estupro e a inserção nas redes virtuais, enfim, um encontro dos princípios de liberdade e igualdade, sem a insistência no rótulo excludente de "feministas".
}

\begin{tabular}{|c|c|c|c|c|}
\hline Qovista Dialectus & Ano 10 & n. 22 & Edição Especial, junho 2021 & p. 134 - 158 \\
\hline
\end{tabular}




\section{REPRESENTACÕES FILOSÓFICAS SOBRE AS MULHERES DESDE...}

Leoni Maria Padilha Henning

fez em seu corpo com esmero, surgindo equipamentos e procedimentos de tratamento, cada vez mais modernos. E, a cada novidade, teremos um público sempre disposto a testá-la obcecado pela busca do corpo perfeito e saudável, difundido pela mídia, distanciando-se daquela visão antropológica essencialista que não pode mais atingir universalmente todas as mulheres - diante do que se defende a individualidade de cada uma.

Os fatores revelados nesses dificultosos pleitos e conquistas pela luta de algumas mulheres e expansão gradativa do gênero feminino nos anos que se seguem, tiveram sustentação na visão preponderante iniciada na modernidade, a qual reservou um lugar condizente à mulher durante o período, de acordo ao que se entendia fosse esse lugar! Contudo, a pós-modernidade, com sua perspectiva pós-estruturalista, postula o interesse em se ater nas performances vinculadas nas contingências, não objetivando a busca por significados absolutos e universais supostamente embutidos nas palavras, símbolos ou estruturas.

Modernidade, a exaltação da "razão" - Ocupar-nos-emos neste momento da visão de alguns filósofos com respeito ao "ser feminino" demonstrada em suas representações, manifestações e narrativas. Entendemos que tais descrições do feminino impregnou a modernidade de uma visão favorecedora da hierarquização social estabelecida e oportunidades atribuídas aos segmentos de gênero, enraizando-se na visão de mundo dos anos subsequentes, sofrendo enfrentamento a partir dos novos desafios descerrados pelas mulheres.

É evidente que nossa empreitada pela história do pensamento nos impõe uma seleção dos autores, a nosso ver, emblemáticos diante da questão central deste nosso trabalho. Assim, inicialmente, elegemos Jean-Jacques Rousseau (1712-1778) que já se manifestou, de algum modo, numa das passagens dessa discussão. Zirbel (2011, p.64) reforça a importância do filósofo genebrino nesse debate, porém menciona a opinião de muitas feministas que o tem como responsável em reforçar a exclusão das mulheres na política e na produção do conhecimento do século XVIII, oportunidade anunciada já em Descartes com sua sugestão de emancipação humana. "Rousseau, no entanto, teria instrumentalizado esta teoria a favor dos homens" (ZIRBEL, 2011, p. 11), pontuando sua racionalidade enquanto as mulheres eram naturalizadas como corpos sensíveis - o que, evidentemente, impactou os processos de ensino e a aprendizagem em relação aos sexos. Zirbel volta a argumentar: "As dicotomias criadas a partir dos métodos educacionais e dos discursos oficiais do século XVIII criam a ideia de mulher como um ser desprovido de razão, voltado às coisas práticas e sensíveis”. Em seu Emilio ou Da Educação (1995), o filósofo estabelece um seu preceito básico, a partir do que tudo o que o ser humano vier a executar na sociedade o fará de modo adequado: "Viver é o oficio que

\begin{tabular}{|l|l|l|l|l|}
\hline Qonista Dialectus & Ano 10 & n. 22 & Edição Especial, junho 2021 & p. 134 - 158 \\
\hline
\end{tabular}


quero ensinar-lhe [...] Nosso verdadeiro estudo é o da condição humana" (ROUSSEAU,1995, p. 14). Tendo dedicado a maior parte da obra à formação de Emilio, no Livro V dedica-se a se aprofundar no conhecimento da mulher, Sofia, a quem busca educar para ser a companheira do seu discípulo. É particularmente neste Livro que encontramos muito do que o autor entende sobre o gênero feminino. Pedagogia e política estão muito próximas no pensamento do genebrino, sendo a Educação um tema que lhe é muito caro, uma vez que conhecer os seres humanos a partir da sua natureza revelada na diferença entre os sexos permite engendrar a proposta para uma sociedade ideal - preconizada em seu Contrato Social. Não estranha, portanto, a publicação de ambas as obras em 1762: reconstruir a sociedade civil com muitos "Emílio e Sofia", respeitando a sua natureza. Nesse sentido, "Emílio (personificação do humano universal/masculino) é encorajado a progredir rumo à sua emancipação enquanto Sofia não terá a mesma sorte" (ZIRBEL, 2011, p. 64) conquanto não é dotada da mesma racionalidade, força e traços de individualidade para a garantia da autonomia. "Sofia [...] tem sua identidade pensada e voltada ao coletivo. Não há lugar, em seu processo educacional, para o desenvolvimento de um potencial individual, com base na razão, na autonomia e na liberdade" (ZIRBEL, 2011, p. 64-65). Nas palavras do próprio Rousseau (1995) podemos constatar claramente o que pensava a respeito das mulheres. Vejamos:

Na união dos sexos cada um concorre igualmente para o objetivo comum, mas não da mesma maneira. Desta diversidade nasce a primeira diferença assinalável entre as relações morais de um e de outro. Um deve ser ativo e forte, o outro passivo e fraco; é preciso necessariamente que um queira e possa; basta que o outro resista pouco.

Estabelecido este princípio, segue-se que a mulher foi feita especialmente para agradar ao homem. Se, por sua vez, o homem deve agradar a ela, isso é de necessidade menos direta; seu mérito está na sua potência, ele agrada só por ser forte. Concordo que essa não é a lei do amor, mas é a da natureza, anterior ao próprio amor.

$\underline{\mathrm{Se}}$ a mulher foi feita para agradar e para ser subjugada, deve tornar-se agradável ao homem em vez de provocá-lo; sua violência própria está em seus encantos; é por eles que ela deve forçá-lo a descobrir sua força e a usar dela. A arte mais certeira de animar essa força é torná-la necessária pela resistência. Então, o amor-próprio une-se ao desejo e um sai vencedor com a vitória que o outro fá-lo alcançar. Daí nascem o ataque e a defesa, a audácia de um sexo e a timidez do outro, enfim, a modéstia e a vergonha com que a natureza armou o fraco para sujeitar o forte (ROUSSEAU, 1995, p. 492-493, grifos nossos).

Rousseau promove a mulher no sentido de atribuir-lhe especial papel na Educação para a civilização, uma vez que a sociedade teria se corrompido. "É a ti que me dirijo, terna e previdente mãe[...] *A primeira Educação é a mais importante e cabe incontestavelmente às mulheres" (ROUSSEAU, 1995, p. 07). O filósofo adverte quanto às implicações que há no perigo da "saída do estado de natureza" podendo passar para um estado degenerativo de

\begin{tabular}{|c|c|c|c|c|}
\hline Qenista Dialectus & Ano 10 & n. 22 & Edição Especial, junho 2021 & p. $134-158$ \\
\hline
\end{tabular}




\section{REPRESENTACÕES FILOSÓFICAS SOBRE AS MULHERES DESDE...}

“civilização", em razão de uma Educação não-natural ou anti-natureza. "O mundo é o livro das mulheres, quando nele leem mal, a culpa é delas, ou então alguma paixão as está cegando". (ROUSSEAU,1995, p. 540). As mulheres foram feitas para servir e, logo, podem apresentar função instrumental se bem ensinadas para esse fim.

Já em Kant (1724-1804) observamos preocupação com a moralidade da espécie humana, tendo nesse tema lugar central a definição do papel da mulher na sociedade. A descrição que o autor faz das mulheres, apesar da tentativa de não ser rude ou desrespeitoso, encaixa perfeitamente no polo de produção de discursos/verdades do século XVIII que mantém as mulheres afastadas de um projeto de emancipação pessoal e confinadas ao mundo doméstico, com o objetivo de "servir", numa condição de complementaridade entre os sexos. Seguindo a vertente Iluminista, Kant assegura a ênfase na razão como componente de distinção e de superioridade da espécie humana, só que na mulher tal capacidade não apresenta a mesma potência como no homem. Caracterizando a mulher de "belo sexo" e o homem de "sexo nobre", Kant assim advoga:

\footnotetext{
Não se quer dizer, com isso, que a mulher careça de qualidades nobres, ou que o sexo masculino deva ser inteiramente privado da beleza; espera-se, ao contrário, que cada sexo reúna a ambos, de tal maneira que em uma mulher todos os outros traços devam estar ligados a fim de elevar o caráter do belo, que é seu ponto de referência específico; e que, por oposição, dentre as qualidades masculinas sobressaia nitidamente o sublime, como a marca de seu gênero. A isso devem referir-se todos os juízos sobre ambos os gêneros, tanto os de louvor quanto os de censura; toda educação e instrução deve ter isso diante dos olhos, assim como todo esforço no sentido de promover a perfeição moral de um ou outro sexo da espécie humana, a menos que se queira ignorar a estimulante diferença instituída entre eles pela natureza. Pois aqui não basta imaginar que se está diante de seres humanos; é preciso ao mesmo tempo não esquecer o fato de que estes não são de um único tipo (KANT, 2021, p. 08, grifos nossos).
}

Os termos "belo" associado ao sexo feminino e o "nobre" ao masculino são melhor compreendidos quando o autor assim explica: "O belo sexo possui tanto entendimento quanto o sexo masculino; trata-se, porém, de um belo entendimento, enquanto o nosso deve ser um entendimento profundo, expressão que significa o mesmo que um entendimento sublime" (KANT, 2020, p.09). E, acrescenta: "O belo entendimento elege como objeto tudo aquilo que é muito aparentado com o sentimento refinado, e abandona especulações ou conhecimentos abstratos - úteis, porém áridos - ao entendimento diligente, sólido, profundo" (KANT, 2020, p.09). Daí decorre, segundo o filósofo, de se evitar apresentar à mulher disciplinas não palatáveis como a geometria ou física ou outras muito estafantes e masculinas, frias ou especulativas, devendo ser expostas a conteúdos igualmente belos, com sentimentos e por meio de sensações. Todos esses traços se completam na relação entre os sexos. Por conseguinte, se a mulher se comportar justamente em conformidade com seus dotes naturais da beleza,

\begin{tabular}{|c|c|c|c|c|}
\hline Qevista Dialectus & Ano 10 & n. 22 & Edição Especial, junho 2021 & p. $134-158$ \\
\hline
\end{tabular}


exatamente assim é que será admirada e desempenhará atração sobre o sexo oposto. O problema da suposta "fraqueza natural" que tipifica a mulher, em vista da "conservação da espécie", seu principal objetivo de vida, Kant resolve com a metáfora das "máquinas de produção" para esclarecer os diferentes níveis de força e desejo da natureza - a responsável pela "fraqueza feminina"- uma vez que, para haver união estável e racional dos dois sexos é preciso a submissão de uma das partes, isto é, uma combinação de forças para se alcançar a continuidade da espécie humana e o seu bem, visto que no homem se constata uma superioridade física indiscutível. Nesse sentido, não seria possível a igualdade plena entre os sexos, pois a desigualdade ou a sujeição de uma das partes é necessária para impedir a discórdia ou competição, devendo, portanto, ser eliminadas as tentativas de se igualar o casal, garantindo assim o que cabe a cada um para uma união duradoura.

Em sua Antropologia, Kant quer compreender o que o ser humano faz de si mesmo, ou "o que pode e deve fazer como ser que age livremente". Curiosamente, no que diz respeito à situação das mulheres, suas ideias se atêm à descrição do que a sociedade delas faz, pois são limitadas, sem atribuir-lhes autonomia e capacidades próprias a um "homem livre dotado de razão", atributos necessários a esse exercício. Considerando a sua crença na "fraqueza" das mulheres, podemos citar os seguintes exemplos mostrados por Zirbel (2011):

[...] as mulheres têm uma cidadania fraca [...]; a incapacidade jurídica da mulher é reflexo do direito do mais fraco [...]; o homem precisa ter sensibilidade para poupar pesares e dores às mulheres e crianças, e "participar dos sentimentos" destes/as por causa da fraqueza dos/as mesmos/as [...]; o choro (da mulher) é expressão da delicadeza e fraqueza do seu sexo, o homem, por sua vez, não deve chorar pois isso o desqualificaria com aquele capaz de proteger a "parte mais frágil" [...]; a natureza dotou a mulher de menos forca física (e exigindo a proteção de um homem) com o intuito de proteger o feto, e com ele, a espécie humana como um todo (303, p. 198); feminilidades significam fraquezas [...] (KANT apud ZIRBEL, 2011, nota 2, p. 51, grifos do autor $)^{14}$.

Lembremo-nos, mais uma vez de Rousseau, agora com respeito à possível "igualdade" entre mulheres e homens. Vejamos:

[...] A mulher e o homem foram feitos um para o outro, mas sua mútua dependência não é igual; os homens dependem das mulheres por seus desejos, enquanto as mulheres dependem dos homens tanto por seus desejos quanto por suas necessidades; subsistiríamos melhor sem elas do que elas sem nós. Para que disponham do necessário, para que estejam bem, é preciso que o demos a elas, que queiramos dá-lo a elas, que consideremos que são dignas disso; elas dependem de nossos sentimentos, do valor que damos a seus méritos, da importância que prestamos a seus encantos e as suas virtudes. Pela própria lei da natureza, as mulheres, tanto por si mesmas quanto por seus filhos, estão à mercê do julgamento dos homens; não basta que sejam estimáveis, é preciso que sejam estimadas; não lhes basta serem bonitas, é preciso que agradem; não lhes basta ter bom comportamento, é preciso que seu comportamento seja reconhecido como tal; sua honra não está somente em sua conduta, mas também

${ }^{14}$ Essa listagem de ideias kantianas a respeito da mulher pareceu-me extremamente didática e produtiva.

\begin{tabular}{|l|l|l|l|l|}
\hline Q Rovista Dialectus & Ano 10 & n. 22 & Edição Especial, junho 2021 & p. $134-158$ \\
\hline
\end{tabular}




\begin{abstract}
em sua reputação, e não é possível que a mulher que consinta em passar por infame possa um dia ser honesta. Ao agir bem, o homem só depende de si mesmo e pode enfrentar o julgamento público; mas a mulher, ao agir bem, fez apenas metade de sua tarefa e o que pensam dela não lhe importa menos do que aquilo que ela de fato é. $\underline{\text { Segue-se daí que o sistema de sua educação deve ser a este respeito contrário ao da }}$ nossa; a opinião é o túmulo da virtude entre os homens, e seu trono entre as mulheres (ROUSSEAU, 1995, p. 502, grifos nossos).
\end{abstract}

Voltando a Kant, levemos em consideração sua ideia do "direito do mais fraco": o direito e a necessidade de ser protegido pelo mais forte. Mais uma vez é a natureza a autora da regra, em nome da (re)produção da espécie. Medo, timidez, fraquezas caracterizam a mulher, sendo necessárias e naturais, logo requerem do homem proteção frente à sua fragilidade. As características naturais e necessárias para a manutenção da espécie, força e fraqueza, se deslocam do campo físico para o caráter humano - homens e mulheres -, constituindo-se em grupos ou gêneros da mesma espécie. Tais atributos se ampliam em vários outros formando o conjunto próprio ao que é o "feminino" e o "masculino". Percebemos que nesse raciocínio, Kant pensa no processo civilizatório, ao qual todos precisam contribuir com sua parte. E qual é a parte que cabe às mulheres nesse processo? Kant dá várias respostas a essa pergunta, mas a básica parece ser "domesticar/dominar/civilizar" o homem. Logo, a natureza estabelece diferentes formas para o equilíbrio das forças que concorrem para a civilização. O homem é dotado de força física e coragem, mas a mulher tem os dotes naturais de fazer o homem ser atraído por ela com seus gestos, linguagem e decência. Assim, a fragilidade, delicadeza e beleza femininas dirigem a masculinidade na garantia da conservação da espécie, do refinamento cultural e sociabilidade. Com intuito civilizatório, o belo sexo, com sua arte, realiza sua função na sociedade estimulando a polidez e o comportamento cortês entre os varões. Contudo, isso só é possível porque os homens permitem, sendo auxiliados por qualidades superiores, generosidade e condescendência e agem com autonomia. Ademais, não se pode desconsiderar que as mulheres possuem características essencialmente domésticas e relacionais, logo, no contexto público, elas podem mostrar-se excessivamente preocupadas com a aparência e com as rivais na concorrência masculina e, com isso, fazer eclodir suas "tendências histéricas". E, por todas essas manifestações de sua fraqueza natural, as mulheres são inadequadas para gerenciar as questões civis - tendo o homem como responsável pela assunção dos assuntos dessa ordem - e, como tal, elas são consideradas civilmente incapazes ${ }^{15}$.

${ }^{15}$ Zirbel, em seu artigo O lugar da mulher na antropologia pragmática de Kant (2011) esmiuça esses conceitos indicando leituras importantes sobre o tema aos interessados.

\begin{tabular}{|c|c|c|c|c|}
\hline Qenista Dialectus & Ano 10 & n. 22 & Edição Especial, junho 2021 & p. $134-158$ \\
\hline
\end{tabular}


E, assim, chegamos ao tema da menoridade, extensivamente conhecido, no texto Resposta à pergunta: Que é "Esclarecimento"? (Aufklarung, de 05/12/1783), apelo para que a humanidade se encoraje e saia da situação de menoridade, de dependência dos outros para decidir e entender, devendo para isso "servir-se de si próprio". Para isso, é preciso ter coragem, abandonar a preguiça e a covardia, ousar saber (Sapere Aude!). Denuncia aqueles que até preferem pagar para evitar tamanho esforço, e aponta um grave problema: “[...] A imensa maioria da humanidade (inclusive todo o belo sexo) considera a passagem à maioridade difícil e além do mais perigosa, porque aqueles tutores de bom grado tomaram a seu cargo a supervisão dela [...]" (KANT, 2005, p. 64). O filósofo entende ser a saída da menoridade difícil para a maioria, pois se mantem tutelada e presa na condição de "menor", como uma segunda natureza. As teorias da natureza e da incapacidade jurídica da mulher (e por que não "de espírito”!) eram próprias ao século XVIII, ideias que vinham já no processo dos séculos anteriores. Assim, a mulher, objeto de nossa análise neste estudo, segundo Kant, apresenta qualidades inerentes à sua natureza como a fragilidade, beleza e habilidades "curiosas" para civilizar o sexo nobre. É evidente que Jean-Jacques Rousseau pode muito bem juntar-se a tais argumentos.

Numa versão distinta quanto ao tema das mulheres, mas não totalmente contrária ${ }^{16}$ aos filósofos acima mencionados, vamos encontrar Auguste Comte (1798-1857) projetando um plano para a correção dos rumos instaurados pelas revoluções burguesas, que levaram à desorganização das sociedades ocidentais. Incorporando as mulheres no Sistema Universal cujo programa indicava as novas orientações instituídas sob a insígnia dos princípios do Amor, Ordem e Progresso, oferecia acolhimento às mulheres para a sua proteção frente aos males sociais diante dos quais poderiam estar à mercê como pobreza e prostituição. Por isso, o papel feminino de baluarte da humanidade e santo destino social, com a condição de ter o homem como seu sustentáculo. O Positivismo enquanto herdeiro do Iluminismo, se insere em uma tradição de escola racionalista e é considerado a última utopia moderna, num livramento da força de Deus ou de outro ente metafísico para a orientação da humanidade, encontrando na base científica o aporte para as indagações humanas. É inegável o papel que Clotilde de Vaux, a grande paixão de Comte, desempenhou na configuração da mulher em seu Sistema ${ }^{17}$.

\footnotetext{
16 Por trás da figura feminina "grandiosa" de Comte se escondem argumentos defensores da inferioridade feminina, uma visão essencialista de fundo empirista que se apoia na lei causal ou na conjunção constante entre eventos, isto é, se A, então B, logo, se mulher, então, inferior, fenômeno que se observa em todas as sociedades e em grande parte das espécies.

${ }^{17}$ Comte teve três importantes referências femininas, mulheres completas, virtuosas e admiráveis: sua paixão maior, Clotilde de Vaux, a Grande Mãe (em contraste com sua maldosa esposa, Caroline Massin, de quem se divorciou após 17 anos de casamento - a representante de Eva, a Pecadora); sua mãe, Rosalie Boyer Comte; e sua filha adotiva, Sofia Bliaux Thomas.
}

\begin{tabular}{|l|l|l|l|l|}
\hline Qovista Qialectus & Ano 10 & n. 22 & Edição Especial, junho 2021 & p. 134 - 158 \\
\hline
\end{tabular}


Entendendo a mulher como aquela que deveria manter-se circunscrita ao espaço do lar, como esteio moral da família e da sociedade em geral, Comte lhe estabelece um papel destacado para a restauração do Ocidente. Não é que o Amor seja exclusivo das mulheres, mas as verdadeiras qualidades associadas a esse sentimento como a pureza e o altruísmo eram, para o filósofo, próprias da mulher. Logo, seria preciso prover a humanidade com a cultura do "sentimento", num contraponto ao industrialismo resultante da racionalidade dos homens. Amar significa, no caso das mulheres, dedicação completa ao Santuário do lar, à obediência às suas obrigações, à consciência de seu destino social como educadora da humanidade, o baluarte moral. Aliás, a mulher é ela própria a representante do ente abstrato, a deusa Humanidade, numa santificação muito próxima à Nossa Senhora cristã, ser imaculado. Para que isso tudo se realize, é preciso que as mulheres obtenham a mesma formação inicial dos homens, após o que, cada um se dirige à instância social a cada um deles reservada, ou seja, a privada às mulheres; a pública, aos homens. No primeiro caso, tendo sido educada dentro do Sistema Positivo, à mulher cabe educar sua prole no que diz respeito as primeiras noções da Educação dos sentimentos, estética e as primeiras letras, até que, prontos para a continuidade dos ensinamentos das sete ciências, seus rebentos sejam encaminhados ao processo restante da Educação positiva. Tal Sistema de Educação Universal proposto no Sistema Positivo garante, segundo o filósofo, o desenvolvimento de um espirito enciclopédico, social, solidário e altruísta, afeito ao Amor, à Ordem e ao Progresso. As leis positivas que regem o mundo natural e social fornecem, portanto, as respostas racionais cientificamente incontestáveis na busca da verdade, portanto, são de validade universal. Tal cientificidade associada à industrialização, oferece o aporte seguro à modernização e aos princípios mencionados e que são orientadores da Moral Positiva. É nesse contexto de interrelações que percebemos a atuação da mulher para a referida corrente de pensamento, de cuja inspiração os motes de "rainha do lar", "anjo tutelar", "sexo afetivo", "santa mulher" somos herdeiros, o que na sala de aula ganha reforço para a interpretação da dedicação feminina como a da "mestra - missionária". A moral autoritária ordenava à mulher a função de protetora dos valores estabelecidos em sua casa, na Educação dos seus filhos, em suas atitudes e responsabilidades. Antes de representar uma "força laboral ou objeto de consumo", Comte instaura como lume a grandiosidade feminina para a moral "regeneradora" destacando sua pureza, sua capacidade de obedecer ao pai e ao marido, sua angelical disposição de enfrentar o sofrimento sem sucumbir à desistência de seu espírito social de doação, dedicação e solidariedade. Diferentemente do homem, senhor supremo merecedor da obediência feminina, tipicamente forte, protetor e racional, a mulher é dotada de "emoção".

\begin{tabular}{|c|c|c|c|c|}
\hline Qovista Dialectus & Ano 10 & n. 22 & Edicão Especial, junho 2021 & p. $134-158$ \\
\hline
\end{tabular}




\section{REPRESENTACÕES FILOSÓFICAS SOBRE AS MULHERES DESDE...}

Contudo, elas merecem cuidados frente ao perigo de descambarem para o desequilíbrio "infantil", choros e teimosia a fim de conquistarem o que ardentemente desejam. Também, por sua beleza e vaidade, exigem vigilância constante para não caírem na leviandade. Por tudo isso, o autor estabelece o que cabe à mulher no Sistema Positivo, de acordo com a excelência dos seus sentimentos brotados do seu coração, essenciais para a reforma de um mundo ajustado à racionalidade moderna.

Interessante considerarmos que na contemporaneidade, junto ao movimento feminista observamos a negação da ideia de "natureza sexual humana", visto que segundo a visão antropológica predominante tanto mulheres quanto os homens podem assumir com igual competência os mesmos domínios sociais. Ademais, há uma resistência de muitas mães de não mais educarem suas filhas segundo os valores idealizados de "príncipes" e "princesas" para que se preparem melhor para a diversidade de funções que devem executar na sociedade em igual pé de igualdade. Há ainda uma tendência de ressignificação desses contos para as questões raciais.

Impacto dos modelos antropológicos apresentados na Educação escolar, no que diz respeito, especialmente, às "professoras" - A origem da Educação moderna é decorrente das novas exigências de um período agitado por transformações tal nos referimos quando apresentamos a modernidade com o industrialismo, as crenças no Progresso nutridas por um forte otimismo, dentre outros fatores. Surgem e são propagadas as ideias iluministas e concepções antropológicas e educacionais num tempo de utopias e de necessária modernização. Certamente, a visão moderna sobre as mulheres, aqui mostrada, acarretou num importante impacto na figura da "professora". Assim, a concepção sobre o lugar "social" possível às mulheres nos séculos XIX e XX seguem as diretrizes já anteriormente discutidas, acarretando às "professorinhas", em grande parte provenientes das classes populares, certo prestígio, uma conquista. Exemplos marcantes para essas "educadoras" vieram de referências até hoje mencionadas, como a médica dedicada à Educação, Maria Montessori (1870-1952), notabilizada por um método que leva o seu sobrenome, ou Pauline Kergomard (1838-1925), fundadora da escola maternal, dentre outras. A situação se modifica com o surgimento das Escolas Normais ${ }^{18}$ que, com a Revolução Industrial, passa a ser necessária para a ampliação e

\footnotetext{
${ }^{18}$ A primeira Escola Normal no Brasil para a formação de profissionais para atuarem no primário foi criada na Província do Rio de Janeiro, em 1835. Com a República, a Educação e formação dos professores se mostra mais importante para o fortalecimento dos princípios proclamados em vista da civilidade e da formação moral do povo do que exatamente teria fins conteudistas. Inicialmente, as Escolas Normais visavam estudantes masculinos, mas por questões econômico-sociais incorporaram as mulheres dos orfanatos, solteiras, público que vai se ampliando gradativamente (Para o aprofundamento desse assunto consultar: VILLELA, 2000).
}

\begin{tabular}{|c|c|c|c|c|}
\hline Qovista Dialectus & Ano 10 & n. 22 & Edição Especial, junho 2021 & p. $134-158$ \\
\hline
\end{tabular}


melhoria da escolarização no atendimento a um maior número de pessoas. Muitos pensadores contribuíram para isso como Rousseau, Pestalozzi, Condorcet, dentre muitos, que com suas críticas à sociedade da época, provocaram iniciativas para o estabelecimento de novos modelos escolares e formação de professores. As mulheres começaram a tomar esse espaço, justamente pela migração dos homens a novos postos e melhoria pecuniária da "sociedade moderna". Porém, pelas suas qualidades delicadas e maternais, as mulheres também serviam nos cuidados aos doentes tanto que na Primeira Guerra elas eram chamadas pela Cruz Vermelha a se alistarem. Porém, nos espaços de cultura e atuação profissional, a absorção da atividade feminina era reduzida.

No Brasil e no mundo, em fins do século XIX e começo do século XX, havia uma presença muito restrita de mulheres no mundo das artes e também no mundo das ciências. Esses espaços eram tidos como de domínio dos homens. Elas ficavam à margem do contexto de produção artística e dos discursos da história da arte. Às mulheres, a sociedade impunha a esfera privada e profissões como o magistério que remetiam à educação e cuidado das crianças, similar ao papel de mãe e educadora, elas não eram bem aceitas nos espaços artísticos [..] A pouca presença delas no âmbito artístico internacional, nacional e paranaense, não deve ser compreendida por uma ausência de mulheres talentos, mas por uma exclusão feminina nas carreiras de formação artística, uma vez que o ingresso em cursos superiores e a profissionalização só foram permitidos a elas, a partir de 19 de abril de 1879, quando D. Pedro II faz aprovar uma lei que concedia essa autorização. A iniciativa do Imperador teria se dado devido ao episódio ocorrido com Augusta Generosa Estrela, que ao se diplomar em Medicina, em 1876, em New York, com uma bolsa de estudos concedida pelo próprio Imperador, foi impedida de exercer a profissão ao retornar ao Brasil [...][Às mulheres] cabia a reprodução - sexual - vista por muito tempo como sendo um "destino natural" das mulheres - e ainda a reprodução do trabalho doméstico, do cuidado, da tradição, de costumes, da moral (PRIORI, 2017, p. 01-03).

Envolver a mulher na docência, especialmente das primeiras letras (cujo ensino não requeria pesados esforços intelectuais), era facilitado pelos seus dotes domésticos, por suas qualidades correspondentes à sua natureza e, também, pelo fato de ela contentar-se com menores salários uma vez que o provedor da família era sempre o homem. Por isso, a elas não eram oferecidos os cargos da linha de frente, inspeção, supervisão ou direção nas escolas. Dentre as atividades de ensino dirigidas às mulheres incluíam ainda as prendas domésticas, mas deixavam de fora aquelas próprias ao ensino secundário ou superior, excluindo, portanto, as disciplinas mais difíceis, mais racionais e abstratas respectivas à mente masculina. Com esse perfil, as mulheres eram primariamente destinadas ao aperfeiçoamento para a sua assunção, disciplina e bons modos na consecução dos encargos advindos do matrimônio.

Em razão das transformações econômicas, demográficas, sociais, culturais e políticas desencadeadas a partir do século XIX e fortalecidas na sequência, uma grande

\begin{tabular}{|c|c|c|c|c|}
\hline Qevista Dialectus & Ano 10 & n. 22 & Edição Especial, junho 2021 & p. $134-158$ \\
\hline
\end{tabular}


participação feminina no mercado de trabalho em geral, e no magistério em particular é observada no Brasil e em muitos outros países. Os homens gradativamente abandonam suas atividades nos cursos primários, as escolas normais vão admitindo um maior contingente de mulheres, de maneira que

Ao longo do século XX, a docência foi assumindo um caráter eminentemente
feminino, hoje, em especial na Educação Básica [...], é grande a presença de mulheres
no exercício do magistério.
De acordo com o primeiro Censo do Professor [1997], 14,1\% da categoria é
constituída de homens e $85,7 \%$ de mulheres. Levantamento realizado pela
Confederação Nacional dos Trabalhadores em Educação (CNTE) com 52 mil
professores brasileiros mostra que $97,4 \%$ dos docentes de 1a a 4a série do Ensino
Fundamental são mulheres. Elas ocupam 80,6\% das 5as até as 8as séries desse ensino
e $60,8 \%$ do Ensino Médio. A pesquisa da CNTE aponta ainda que entre diretores,
coordenadores e supervisores ligados à Educação Básica 90,1\% são mulheres
(VIANNA, 2001, p. 83, acréscimos e grifos nossos).

Vemos assim que a incorporação feminina no magistério do Brasil se alargou no avanço do século $\mathrm{XX}$, mas percebemos que esse processo foi realizado a passos dificultosos e lentos. A "figura da professora" que, por definição, era simplesmente interpretada como possuidora de uma "missão", tinha no magistério a tarefa precípua como garantidora moral da nação, uma espécie de "segunda maternidade", tendo como preâmbulo dessa atividade a preparação para o exercício esmerado da vida doméstica, lar, família, criação dos filhos, culinária, sendo o magistério como profissão, portanto, uma exceção, e impregnado do virtuosismo religioso.

Nas últimas décadas, curiosamente e talvez devido a vestígios dessa mesma visão, observamos uma percepção da figura da "professora como tia", decorrendo disso uma reação para o reconhecimento profissional efetivo do "ser professora". Paulo Freire, por exemplo, em sua obra - duas emblemáticas para a discussão, Professora, sim; tia não (1994) e Pedagogia da autonomia - saberes necessários à prática educativa (1997) - se empenha em oferecer recursos conceituais e teóricos para darem sustentação e estofo à atuação dos professores, objetivando o fortalecimento da profissão (como qualquer outra), não obstante, reconheça a importância dos laços afetivos no desenvolvimento dessas atividades. É facilmente observado que as mulheres, hoje, não estão submetidas a terem uma formação reduzida e voltada a apenas algumas e poucas atividades ou disciplinas no exercício profissional docente. Ao contrário, temos as mais variadas opções e reivindicações para uma justa concorrência no que concerne aos homens, o que é visto com frequência. Mas, um problema ainda persiste: há ainda dificuldades em se garantir salário, oportunidades e participação iguais quanto a dos homens. Esse problema se amplia para além do magistério, como é o caso divulgado pela mídia, recentemente, "Mulheres são apenas $20 \%$ das bancas examinadoras em concursos para juiz"

\begin{tabular}{|l|l|l|l|l|}
\hline Q Rovista Oialectus & Ano 10 & n. 22 & Edição Especial, junho 2021 & p. 134 - 158 \\
\hline
\end{tabular}




\section{REPRESENTACÕES FILOSÓFICAS SOBRE AS MULHERES DESDE...}

Leoni Maria Padilha Henning

tendo a pesquisa revelado que, “[...] nos últimos 10 anos, 30\% das bancas foram exclusivamente masculinas" (POMPEU, 2020).

Perfil da mulher contemporânea e sua atuação como filósofa e professora - Primeiramente, vale a pergunta se há ou não o reconhecimento da presença de mulheres-filósofas na arena masculina da Filosofia. Onde estão as filósofas? Mesmo sendo excluídas, escondidas ou pouco evidenciadas, elas fizeram parte da História da Filosofia. Apesar do controle masculino nas questões filosóficas, pode-se encontrar referências, ainda que poucas, sobre a existência dessas mulheres. A Filosofia não foi e nem é feita apenas por homens, embora a mesma continue associada à figura masculina. Silva (2020) endossa a ideia de que é preciso dar voz às mulheres filósofas, mesmo porque elas têm presença forte em muitos períodos da sua história, embora, o tom masculino da Filosofia ainda seja preponderantemente masculino e, também, pelo fato de que muitas delas sejam citadas apenas como coadjuvantes associadas a um nome reconhecido. Diante do exposto, uma estratégia a partir dos anos 60 que tem sido proposta é o trabalho investigativo de revisão, para mostrar o protagonismo das mulheres na Filosofia - o que, como podemos imaginar, tem sido nebuloso, uma vez que há muitas dificuldades quanto ao reconhecimento do trabalho efetivamente intelectual feminino e as limitações a elas impostas ao longo da história. Contudo, ao revisitar os ensaios, cartas e outras produções autorais, por vezes desconhecidas, percebemos a autonomia de pensamento e o impacto que muitas mulheres produziram (e produzem) no meio acadêmico e social. A reconstituição tem sido uma maneira de sanar a questão sobre haver ou não filósofas. Para Tiburi (2003), as mulheres não só participaram da Filosofia, como de outros setores da sociedade, porém, essa participação se deu de forma tímida. Apesar disso, "mulher e Filosofia" continuam sutilmente separadas. Podemos observar essa separação na escassez feminina nos currículos dos cursos de Filosofia e nos corredores acadêmicos. Assim, precisamos defender uma "Filosofia no feminino", restituindo a presença das grandes mulheres nesse campo abrigado pelo conhecimento e sabedoria, normalmente atribuído aos homens, oportunizando a visibilidade de muitas filósofas que se encontram ocultadas nos espaços de debate, com postura de sombra, heterônomas ou silenciadas pela condição acadêmica marginal que ocupam. Como professoras, as mulheres carregam consigo as marcas de ter sido a elas imputadas características dificultosas às atividades intelectuais. Há necessidade de se retirar as mulheres da inoperância intelectual e cultivo de inferioridade epistêmica ao serem colocadas no universo macro do saber. Essa reflexão contribui para a tentativa de um estudo/análise sobre a condição feminina, quer na Filosofia, quer na Educação. A crença de que um grande homem é feito graças à mulher que o

\begin{tabular}{|l|l|l|l|l|}
\hline Qonista Dialectus & Ano 10 & n. 22 & Edição Especial, junho 2021 & p. 134 - 158 \\
\hline
\end{tabular}




\section{REPRESENTACÕES FILOSÓFICAS SOBRE AS MULHERES DESDE...}

Leoni Maria Padilha Henning

acompanhou, orientou, reforça a "posição feminina de sombra", não obstante seu grau de importância, o que deve ser contemporizado. Tanto a Filosofia quanto a Educação exprimem o espirito “feminino". É preciso que as mulheres tomem, de fato, o seu lugar e presença nesses espaços.

Palavras finais - Como vimos, a modernidade buscou captar as essências representativas do que se acreditava ser a "natureza humana", conceito resultante do esforço racional humano, da sua inteligência abstrativa, da crença em sua capacidade de atingir a Verdade sobre as coisas. Uma vez captadas/elaboradas tais essências, cabia a cada esfera do mundo humano aperfeiçoar o caminho para atingi-las. Assim, a sociedade se ocupava em garantir a "todos" a ordem, a justiça e as leis pautadas nas garantias das ciências e no conhecimento seguro. Os filósofosHOMENS foram os grandes tradutores dessa compreensão que sustentava a busca pelo mundo perfeito, as utopias, em suas vastas obras. Com o tempo presente, caracterizado por muitos como pós-moderno, vemos acontecer o deslocamento desse eixo. Da universalização, segurança, ordem, verdade, padronização e outros, enveredamos para um cenário de defesa/ênfase na flexibilização, na fragmentação, no particular, no local, no questionamento, no convencimento da precariedade do mundo, e por aí vai. Se para as mulheres a modernidade ofereceu um papel a cumprir para o bem-estar geral do mundo humano, pautada em sua "natureza", no momento atual divulga-se outra crença: "a essência humana é construção", portanto, deve ser desmanchada, desconstruída; e, assim, derrubam-se os mitos sobre o par "feminilidade/masculinidade", diante de cujos perfis procura-se outras perspectivas de análise, como também, propõem-se a mescla das tarefas domésticas e sociais destinadas aos sexos de modo indefinido. Embora, estando num mundo de muitas incertezas e a vida sendo colocada em coordenadas mais abertas, talvez, para as mulheres seja a grande oportunidade, operada pelos vários setores da sociedade, para se projetar nos afazeres que sempre sonhou dedicar-se, mas que lhes foram interditados. E, fazê-lo com competência e responsabilidade social. "Criar e recriar-se continuamente", eis a enorme brecha que se abre no mundo humano.

\section{Referências}

AGENCIA BRASIL. Eleições 2020. Brasília, 19/out./2020.

COELHO, Leila Machado; BAPTISTA, Marisa. A história da inserção política da mulher no Brasil: uma trajetória do espaço privado ao público. Revista Psicologia Política, São Paulo, v. 9, n. 17, p. 85-99, Jun. 2009.

DIAS, S. de Fátima. O trabalho da mulher no magistério brasileiro nos séculos XIX/XX. Disponível:http://www.historia.seed.pr.gov.br/modules/conteudo/conteudo.php?conteudo=16 4. Acesso: 17/12/20.

\begin{tabular}{|l|l|l|l|l|}
\hline Q Rovista Dialectus & Ano 10 & n. 22 & Edição Especial, junho 2021 & p. 134 - 158 \\
\hline
\end{tabular}


ENGELS, Friedrich. A origem da família, da propriedade privada e do estado. Tradução de José Silveira Paes. São Paulo: Editora Global, 1984.

FERNANDES, Vera Lúcia F. Pinto. Relações entre ginástica e mulher brasileira: do início do século XX aos dias atuais. EFDeportes.com, Revista Digital. Buenos Aires, Año 15, No 148, Septiembre de 2010.

FRANCHINI, B. S. O que são as ondas do feminismo? Revista QG Feminista. 2017. Disponível em: https://medium.com/qg-feminista/o-que-s\%C3\%A3o-as-ondas-dofeminismoeeed092dae3a. Acesso em: 30/05/21.

FREIRE, Paulo. Professora sim, tia não - cartas a quem ousa ensinar. $5^{\text {a }}$ ed. São Paulo: Editora Olho D’água, 1994. Terra, 1996.

Pedagogia da autonomia-saberes necessários à prática educativa. São Paulo: Paz e

KANT, Immanuel. Textos seletos. Tradução de Floriano de S. Fernandes. $3^{\text {a }}$ ed. Editora Vozes: Petrópolis, RJ, 2005, pp. 63-71.

. Observações sobre o sentimento do belo e do sublime. Disponível: http://www.laifi.com/laifi.php?id_laifi=501\&idC=102072\#. Acesso: 23/05/21.

MARX, Karl; ENGELS, Friedrich; LENIN. Sobre a mulher. Col. Bases 17. São Paulo: Global, 1979.

MELLO, José Mauricio S. de. O positivismo e a educação provida pelas mulheres como fator de transformação epistemológica operada entre os séculos XIX e XX. Dissertação de Mestrado. Londrina, UEL, Departamento de Educação, 2007. Disponível em:

http://www.uel.br/pos/ppedu/images/stories/downloads/dissertacoes/2007/2007\%20\%20MELLO,\%20Jose\%20Mauricio\%20Santiago\%20de.pdf. Acesso: 18/05/21.

ORGANIZAÇÃO PARA A COOPERAÇÃO E DESENVOLVIMENTO ECONÔMICO Education at a Glance. OECD Indicators - Brazil, 2019. Disponível: https://read.oecdilibrary.org/education/education-at-a-glance-2019_246ea76d-en\#page1. Acesso: 19/05/21.

SILVA, Juliana P. B. da. Mulher e filosofia: onde estão as filósofas? Disponível https://editora.pucrs.br/anais/semanadefilosofia/XIII/15.pdf. Acesso: 16/12/20.

POMPEU, Ana. Mulheres são apenas $20 \%$ das bancas examinadoras em concursos para juiz. JOTA. Brasília, 22/08/20. Disponível: https://www.jota.info/paywall?redirect_to=//www.jota.info/justica/mulheres-sao-apenas-20das-bancas-examinadoras-em-concursos-para-juiz-22082020. Acesso: 26/05/21.

PRIORI, Claudia. Mulheres e a relação com a arte: implicações de gênero nas expressões artísticas (Paraná, fim do séc. XIX e começo do séc. XX). Seminário Inter Fazendo Gênero 11/13th Women's Worlds Congress (Anais Eletrônicos), Florianópolis, 2017.

\begin{tabular}{|c|c|c|c|c|}
\hline Qovista Dialectus & Ano 10 & n. 22 & Edição Especial, junho 2021 & p. $134-158$ \\
\hline
\end{tabular}


SILVA. J. P. Borges da. Mulher e filosofia: onde estão as filósofas? Disponível em https://editora.pucrs.br/anais/semanadefilosofia/XIII/15.pdf. Acesso: 17/12/20.

ROUSSEAU, Jean Jacques. Emílio ou da educação. Tradução de Roberto Leal Ferreira. São Paulo, Martins Fontes, 1995.

TIBURI, Marcia. As mulheres e a filosofia como ciência do esquecimento. Reportagem. SBPC/Labjor, 2003. Disponível: https://www.comciencia.br/dossies-172/reportagens/mulheres/15.shtml. Acesso: 28/05/21.

VIANNA, C. Pereira. O sexo e o gênero da docência. Cadernos Pagu, Campinas, SP, n.1718, p. 81-103, 2001/02. Disponível em: https://periodicos.sbu.unicamp.br/ojs/index.php/cadpagu/article/view/8644555.

Acesso: 29/05/21.

VILLELA, H. de O. S. O mestre-escola e a professora. In: LOPES; FARIA FILHO; VEIGA (org). 500 anos de educação no Brasil. Belo Horizonte: Autêntica, 2000, p. 95-134.

ZIRBEL, Ilze. O lugar da mulher na antropologia pragmática de Kant. Kant e-Prints. Campinas, Série 2, v. 6, n. 1, p. 50 - 68, jan.- jun., 2011.

\begin{tabular}{|c|c|c|c|c|}
\hline Qovista Dialectus & Ano 10 & n. 22 & Edição Especial, junho 2021 & p. $134-158$ \\
\hline
\end{tabular}

